\section{Diversity, distribution and vegetation assessment in the Jahlmanal watershed in cold desert of the Lahaul valley, north- western Himalaya, India}

\begin{abstract}
Rawat YS ${ }^{(1)}$, Vishvakarma SCR ${ }^{(1)}$, Oinam SS ${ }^{(2)}$, Kuniyal JC (2)
Relict vegetation in the Jahlmanal watershed is sparsely and scantily distributed on forest land. Farmers maintain tree species (Salix spp., Populus spp., Hippophae rhamnoides) on the boundaries of terraced agriculture fields to meet the fodder and fuel wood requirements. Juniperus macropoda was found in relict forest patches in sparse and stunted conditions. The density of Salix fragilis was 3340 trees ha ${ }^{-1}$ under agroforestry and 5520 trees ha ${ }^{-1}$ under forestry. The density of $\mathrm{J}$. macropoda was 4200 tree ha $^{-1}$ in natural forest followed by 700 tree ha- $^{-1}$ in agroforestry and 160 tree ha $^{-1}$ in managed forestry systems. The agroforesty system of the watershed consists of $30 \%$ trees, $35 \%$ small trees and $35 \%$ shrubs species. Shrubs contributed the highest density with $59.1 \%$ of the total, followed by density of trees $(29.5 \%)$ and small trees $(11.3 \%)$. Trees contributed highest basal area in all the three systems, i.e., agroforestry, forestry and forest. The relict forest patches are subjected to deforestation due to anthropogenic pressure, hence in-situ and ex-situ conservation are required. Efforts are needed for plantation of ecologically suitable multipurpose tree species with indigenous species in the watershed. Technological interventions are also required to improve the quality and resistance against drought and climate change.
\end{abstract}

Keywords: Vegetation analysis, Agroforestry, Forestry, Forest, Watershed, Lahaul valley, Cold desert, Indian Himalaya

\section{Introduction}

Nearly $74809 \mathrm{~km}^{2}$ area of India falls under cold deserts, of which about $35 \%$ is in $\mathrm{Hi}$ machal Pradesh (Anonymous 1993). Of the total area of cold desert, $25 \%$ of the area occurs in Lahaul and Spiti division of the Lahaul-Spiti district. The Jahlmanal watershed falls within the Lahaul division, the Jahlma nala (the main stream of watershed) is one of the tributaries of the River Chandra-

(1) G.B. Pant Institute of Himalayan Environment and Development, KosiKatarmal, Almora 263643 Uttarakhand, India; (2) G.B. Pant Institute of Himalayan Environment and Development, Himachal Unit, Mohal-Kullu 175126 Himachal Pradesh, India.

(a) Yashwant Rawat

(yas_rawat@yahoo.com)

Received: Dec 24, 2009 - Accepted: Apr 21, 2010

Citation: Rawat YS, Vishvakarma SCR, Oinam SS, Kuniyal JC, 2010. Diversity, distribution and vegetation assessment in the Jahlmanal watershed in cold desert of the Lahaul valley, north-western Himalaya, India. iForest 3: 65-71 [online: 2010-05-17] URL: http://www.sisef.it/iforest/show.php? id $=532$
Bhaga (Chenab). In the watershed, land use pattern has changed from traditional subsicash crops, vegetables and fruits (Singh et al. 1997, Oinam et al. 2005). These changes are primarily responsible for degrading the quality of environment and vegetation pattern in a system. Among the prime land use components, the forest cover in the watershed is under a tremendous change due to anthropogenic pressure since a last couple of decades (Vishvakarma et al. 2005a, Vishvakarma et al. 2005b, Rawat 2006). The vegetation pattern in the watershed mainly include dry temperate and alpine (Anonymous 1995, Aswal \& Goel 1989, Aswal \& Mehrotra 1994). Forest cover is very poor in the watershed and high anthropogenic pressures are observed in relict forest patches. A century back, there were evidences of dense Juniperus forests in the watershed area. However, due to illegal harvesting of the forests for fuelwood, timber and other religious purposes (Rawat et al. 2006), there are now very few isolated and patchy pockets of Juniperus forests in the watershed (Anonymous 1995).

Scant rainfall, massive snowfall, high wind velocity, extreme temperature conditions from low to high, high UV radiation, intense solar radiation and extremely xeric condistence farming to high yielding variety of tions are the common features of the watershed similarly as cold desert. These climatic factors determine and regulate the life process and distribution pattern of the vegetation (Watt 1981, Dhar et al. 1994). Generally, an extreme cold climatic condition of the watershed is reflected in the existing vegetation (Kuniyal et al. 2005, Rawat et al. 2006). Vegetation is very sparsely distributed in three systems (i.e., agroforestry, forestry and forest) in the watershed. However, most of the south facing slopes is denuded.

At present, nearly $7.9 \%$ area of the district Lahaul-Spiti is under scant forest cover (Anonymous 1995). Scattered patches of Betula utilis and Pinus wallichiana on north-facing slopes, and Juniperus macropoda patches occur on dry south facing slopes. Around settlements willow based agroforestry systems, and willow and poplar plantation are found. These make up the basic cold desert vegetation elements of the Lahaul valley (Rawat et al. 2006). An agro-ecosystem with willow (Salix spp.) based agroforestry and forestry (willow plantation; hereafter referred as forestry in the text) are the main source of fuelwood and fodder in the Lahaul valley (Singh et al. 1997, Kuniyal et al. 2002, Kuniyal et al. 2004, Vishvakarma et al. 2005a, Vishvakarma et al. 2005b, Rawat et al. 2006). There are two species of willow (Salix fragilis and $S$. alba) which are widely cultivated and 10 other wild shrub species of willow are also found in the valley (Aswal \& Mehrotra 1994).

A few studies have been conducted so far in the Lahaul valley related to indigenous knowledge (Singh et al. 1997), ethno-botanical studies of the plant taxa (Sood et al. 2001), fuelwood production and multi-purpose uses of the Seabuckthorn (Kuniyal et al. 2002), energy and monetary efficiencies of introduced cash versus traditional crops (Kuniyal et al. 2004), and cultivation prospects of Saussurea costus and the causes of its decline in the Lahaul valley (Rawat et al. 2004, Kuniyal et al. 2005). Studies have also been conducted on land use and land cover changes in the Jahlmanal watershed and traditional kuhl irrigation systems and water sharing mechanism through kuhl of the cold desert in the Lahaul valley (Oinam et al. 2005, Vishvakarma et al. 2005a, Vishvakarma et al. 2005b). Therefore, present study deals with vegetation analysis of natural forests, agroforestry and forestry systems with following objectives:

1. diversity, distribution, density, basal area and importance value indices (IVI);

2. utilization pattern;

3. species richness;

4. vegetation characteristics and conservation. 


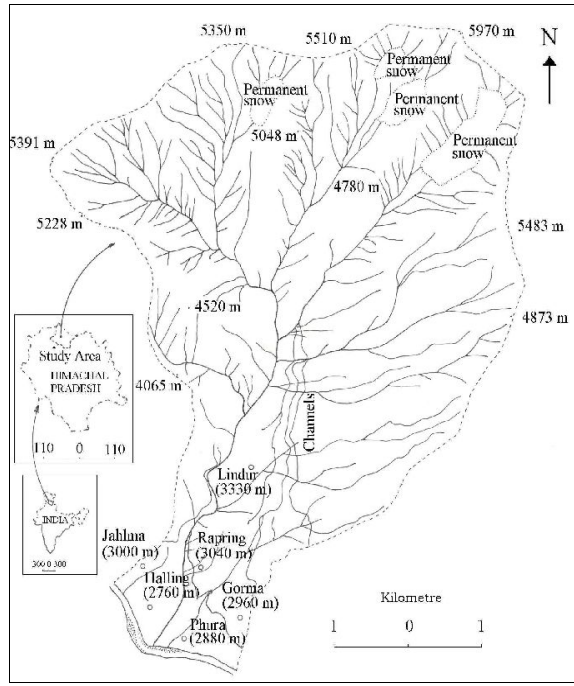

Fig. 1 - Drainage system of the Jahlmanal watershed in the Lahaul valley.

\section{Study area and climate}

\section{Geographical location}

Jahlmanal watershed, which is in the area of a proposed biosphere reserve, is a typical representative of the Lahaul valley. The watershed is situated almost in the centre of the valley. The watershed in the Lahaul valley is located at the bank of the Chandra-Bhaga or Chenab river on the Keylong-Udaipur road (Fig. 1) and occupies approximately $33 \mathrm{~km}^{2}$. The watershed starts at the confluence of Jahlmanal and Chandra-Bhaga at an elevation of $2723 \mathrm{~m}$ asl in the south and end at $3600 \mathrm{~m}$ asl in the north. Agriculture is practiced up to $3400 \mathrm{~m}$ asl at Lindur village. The watershed has natural (forest and alpine pastures) and human dominated (agriculture, horticulture, agroforestry and forestry) systems, which represent most of the valley. Within the watershed, there is a great diversity of land use due to topography and population. Because, there is an expansion of built-up and settlement land by $35.4 \%$ in 2001 as compared to that of 1991 due to population growth within the watershed. During the last decade (1991 2001) the population increased by $87.3 \%$ in this watershed area (Oinam et al. 2005). In general, the steep slopes of the region were for forest or grassland and the areas with gentle slopes were extensively cultivated.

\section{Climate and vegetation zone}

Climatically, the Lahaul valley is cold and arid with low rainfall, high snowfall and severe winters. Broadly, the valley has two seasons, short lived summers and prolonged severe winter. The nearest meteorological station for the Jahlmanal watershed is at Tandi, $12 \mathrm{~km}$ far from Jahlma at the confluence of the Chandra and Bhaga rivers at an altitude of $2846 \mathrm{~m}$ asl. On an average (1985 to 2000) monthly highest maximum temperature is $17.7^{\circ} \mathrm{C}$ in July and lowest is $-3.5^{\circ} \mathrm{C}$ in January (Fig. 2). Lowest ever recorded minimum temperature is $-28^{\circ} \mathrm{C}$ in January 1989. Average annual snowfall is $485 \mathrm{~mm}$. The months of February and March received more than $50 \%$ of the snowfall. However, smaller snowfall is common from December to April. Rainfall is scarce although showers occasionally occur May to September. The annual average rainfall is $267 \mathrm{~mm}$.

\section{Agriculture and vegetation}

Agricultural activities are performed during the short summer season (May to September). A few decades back, agricultural practices were mainly traditional with rich crop diversity (Fagopyrum spp., Hordeum himalayense, Saussurea costus, Inula recemosa), but recently people have turned towards introduced cash crops such as potatoes, peas and hops. These major cash crops have been a source of income under ensured irrigation through kuhls (water channels). In the watershed, the largest area of cultivated land was found to be concentrated between 2801 to $3000 \mathrm{~m}$ asl in the villages (Oinam et al. 2005). This was due to availability of relatively gentle terrain favourable for cultivation combined with the accessibility of irrigation facilities in this altitudinal range. Cash crops are exported and food items, fuelwood and timber are imported from adjacent regions such as the Kullu valley.

Salix spp. and Populus spp. are important species in the agroforestry and forestry systems of the watershed. However, Hippophae rhamnoides was found in dense patches along the slopes in watershed area. J. macropoda was the dominated tree species in the forests system on the slopes of watershed, which remains usually dry. Scrublands (grassland with tussocks of wild rose) are the important land cover species upon which wildlife and domesticated animals survive (Rawat et al. 2006).

\section{Village systems}

Six revenue villages, Jahlma (3000 m asl), Haling (2760 m asl), Phura (2880 m asl), Rapring (3040 m asl), Gorma (2960 m asl) and Lindur (3330 m asl) are located in the watershed. Settlements in the watershed ranged from $2760 \mathrm{~m}$ in Haling to $3330 \mathrm{~m}$ in Lindur villages, whereas other villages fall in between Haling and Lindur (Fig. 1). Revenue area under Gorma and Jahlma were nearly same, whereas the third largest village in the area was Phura. The other three remaining villages, such as Rapring, Lindur and Haling, were relatively small in area compared to Gorma and Jahlma. The number of households and people living therein were larger in Jahlma followed by Gorma. The total population increased from 839 in 1991 to 1571 in 2001 with an annual population growth rate of $8.72 \%$ (Oinam et al. 2005).

\section{Forest and scrubland}

The area under the forest land and scrubland (grassland with patches of Rosa webbiana, Berberis pseudumbelata and Ribes grossularia) is vegetated beyond the highest altitude village Lindur; after that the area is totally barren with stony outcrops and snow bound areas which remain devoid of any shrubs. Here, land use practices cover more than $90 \%$ of the total area of the watershed $\left(33 \mathrm{~km}^{2}\right)$. Vegetation cover in the natural forest land was very sparse, and dominated by $J$. macropoda. This species is occasionally associated with Crataegus songarica and $R$. webbiana. From the imagery (Fig. 3a, Fig. 3b), it was observed that the extent of forest cover was reduced slightly during the period 1991-2001. Scrublands are also important land cover in the watershed supporting wild and domesticated grazing animals (Oinam et al. 2005). The colour for these scrublands on the false colour composites (FCCs) was represented by light yellow or grey to dark brown. The decrease in the vegetation cover in the forest and scrubland

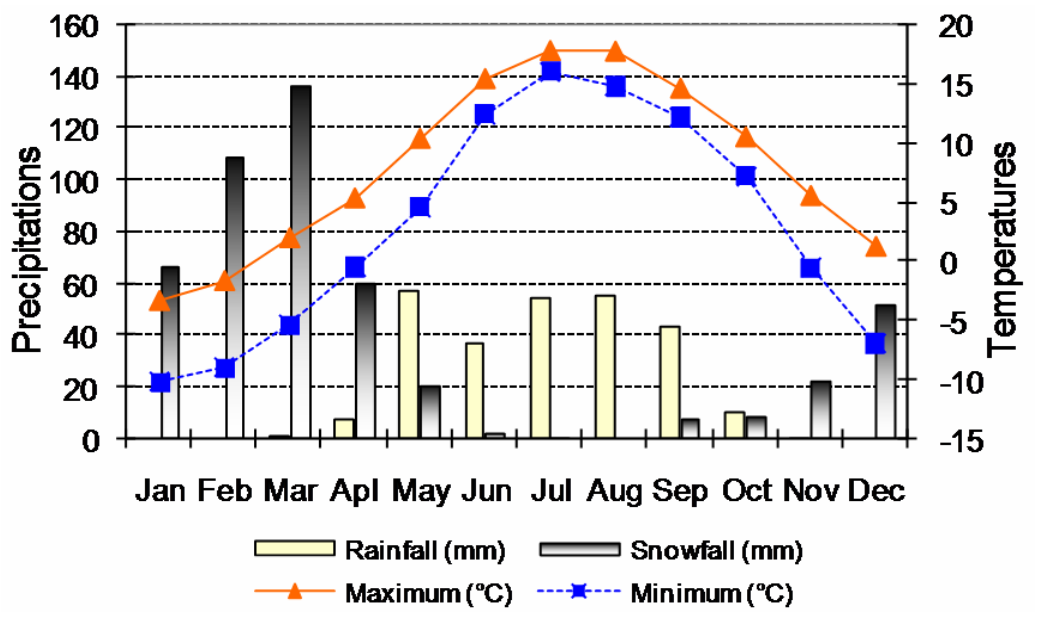

Fig. 2 - Precipitation and temperature conditions in cold desert of the Lahaul valley. 
Fig. 3 - Satellite imagery of Jahlmanal watershed (source: Oinam et al. 2005). (a) Taken on November 19, 1991 at 1647 hours (IST),

SAT-ID: IRS-1A,

Data-ID: 52D14; (b) taken on November 13,

2001 at 1126 hours (IST), SAT-ID: IRS1D, Data-ID: 52D14.
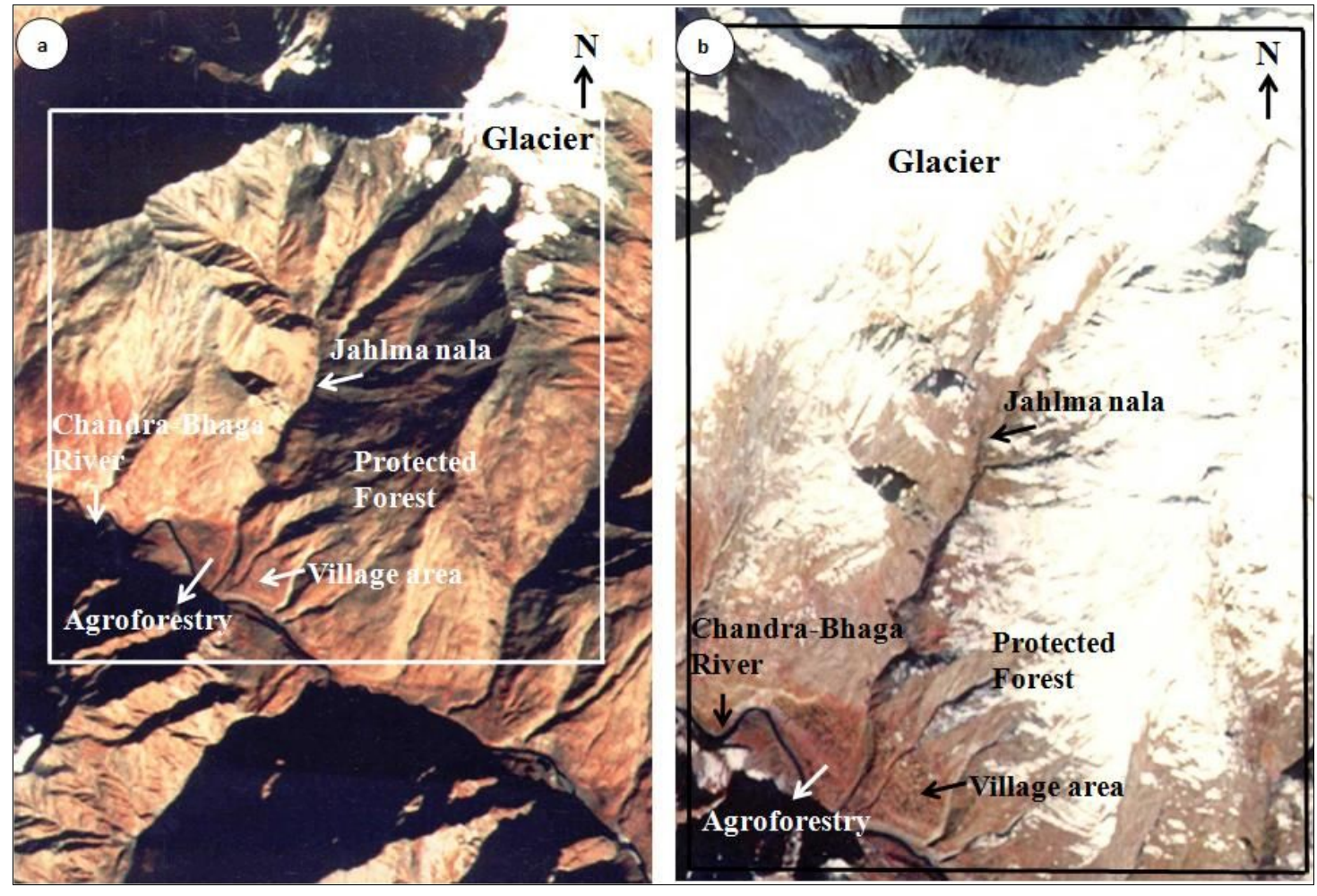

was mainly due to the excessive extraction of forest products. However, there was no substantial change in forestland and scrubland during the study period, as these lands now were controlled directly by the Government. It is assumed in the Jahlmanal watershed that the extraction of forest resources would increase considerably in the future with population growth increases. This excessive exploitation will intensify the pressure on the existing scant forest cover causing environmental problems, such as forest resource depletion and land deterioration.

\section{Materials and Methods}

\section{Survey and sampling}

The study of vegetation analysis was carried out during the peak growing season using transects along altitudinal gradients and different marked features of topography. Three transects were laid down starting from a base of the slope to the end of the vegetation zone in each selected site. The transects were $200 \mathrm{~m}$ apart from each other. The quadrats $\left(10 \times 10 \mathrm{~m}^{2}\right)$ were laid down for tree and shrubs in a line running method (Kershaw 1973) along slopes with an interval of $10 \mathrm{~m}$. Herbarium specimens were collected, dried in a plant press and identified by a professional taxonomist at the Institute. Diameter at breast height $(\mathrm{DBH})$ of tree species was measured at $1.37 \mathrm{~m}$ from ground level. However, in the case of shrubs diameter was measured at $5 \mathrm{~cm}$ above ground level. Individuals of more than $5.0 \mathrm{~cm}$ diameter were considered as trees, individuals between 1.7 $\mathrm{cm}$ to $5.0 \mathrm{~cm}$ diameter were considered as saplings or shrubs (as the case may be Knight 1963).

\section{Data analysis}

Frequency, density and abundance were calculated following Curtis \& McIntosh (1950). The abundance: frequency (A/F) ratio was used to interpret distribution pattern of species. This ratio indicates the regular $(<0.025)$, random $(0.025-0.05)$ and contagious ( $>0.05$ ) distribution pattern (Curtis \& Cottom 1956). Basal area, relative density, relative frequency and relative dominance were calculated following Phillips (1959) and the sum of the relative density, relative frequency and relative dominance was treated as importance value indices (IVI) for various species (Curtis 1959). Species richness, dominance concentration (cd), evenness and similarity index were also analysed. The species richness is the number of species per unit area (Mac Arthur 1965, Whittaker 1975). Agroforestry, forestry and forest system vegetation will be considered separately and presented separately. Species diversity $\left(\mathrm{H}^{\prime}\right)$ was computed by the Shannon \& Weiner 1963 information index as follows (eqn. $1)$ :

$$
H^{\prime}=-\sum_{i=I}^{s} \frac{N_{i}}{N} \log _{2} \frac{N_{i}}{N}
$$

where, $N_{\mathrm{i}}$ is the total density value for species $i$ and $N$ is the sum of the density values of all the species in that site.

Dominance concentration (cd) was deter- mined by following Simpson's formula (1949) where $N_{\mathrm{i}}$ and $N$ were the same as for the Shannon-Weiner information index as follows (eqn. 2):

$$
C d=\sum_{i=I}^{s}\left(\frac{N_{i}}{N}\right)^{2}
$$

Evenness index (J') was determined according to Pielou (1966).

The utilization patterns of various species were studied by semi-structured questionnaires; interviews held with the family head and experienced individuals. Data was analyzed statistically with SYSTAT, the data of three systems (agroforestry, forestry, forests). The analysis of variance $(\alpha=0.01)$ and Fisher's Least Significance Difference (Snedecor \& Cochran 1968) were used to find out the difference in species richness, density and dominance concentration.

\section{Results}

\section{Vegetation analysis}

The vegetation analysis was shown to have a contagious distribution pattern in the watershed. The farmers maintain tree species on the boundaries of terraced agriculture fields under low density. Salix fragilis, Hippophae rhamnoides, Populus nigra, Prunus cornuta, Prunus armeniaca, Prunus avium, Malus baccata and Crataegus songarica were important agroforestry plant species in the watershed. Other trees and shrubs were also found under agroforestry and forestry systems. Plantations of multipurpose tree spe- 
Tab. 1 - Density, basal area, important value indices, abundance frequency ration, nature and utilization pattern of different plant species occurred in agroforestry system in the Jahlmanal watershed, the Lahaul valley. $(\mathrm{P})=$ planted species, $(\mathrm{N})=$ naturally regenerating species, $\left({ }^{\mathrm{a}}\right)=$ Important value indices, $\left({ }^{b}\right)=$ abundance/frequency.

\begin{tabular}{|c|c|c|c|c|c|c|c|c|}
\hline Groups & Species & $\begin{array}{l}\text { Local } \\
\text { name }\end{array}$ & $\begin{array}{c}\text { Density } \\
\text { ha }^{-1}\end{array}$ & $\begin{array}{c}\text { Basal Area } \\
\left(\mathrm{cm}^{2} / 100 \mathrm{~m}^{2}\right)\end{array}$ & $\mathbf{I V I}^{\mathbf{a}}$ & $\mathbf{A} / \mathbf{F}^{\mathbf{b}}$ & Nature & Uses \\
\hline \multirow[t]{7}{*}{ Trees } & Salix fragilis $\mathrm{L}$. & Beli & 3340 & 961.8 & 100.8 & 0.1 & $\mathrm{P}$ & $\begin{array}{l}\text { Fuel, fodder, small timber, } \\
\text { chewing twig }\end{array}$ \\
\hline & Populus nigra $\mathrm{L}$. & Safeda & 590 & 142.8 & 20.4 & 0.1 & $\mathrm{P}$ & Fuel, Timber \\
\hline & Robinia pseudoacacia L. & Kikar & 180 & 9.1 & 2.8 & 1.4 & $P$ & Fuel, fodder \\
\hline & Juniperus macropoda Boiss. & Shur & 700 & 66.1 & 16.7 & 0.1 & $\mathrm{~N}$ & Incense(Dhoop), Fuel \\
\hline & $\begin{array}{l}\text { Prunus cornuta (Wall. ex Royle) } \\
\text { Steudel }\end{array}$ & Kurun & 130 & 11.2 & 2.6 & 1.0 & $\mathrm{~N}$ & Fuel, fodder, fruit \\
\hline & Juglans regia $\mathrm{L}$. & Akhrot & 40 & 14.6 & 2.0 & 0.5 & $\mathrm{P}$ & Fruit \\
\hline & Total & - & 4980 & 1205.4 & 145.3 & 3.1 & - & - \\
\hline \multirow[t]{8}{*}{ Small-trees } & Malus baccata (L.) Borkh. & Leejho & 70 & 13.9 & 2.8 & 0.4 & $\mathrm{~N}$ & Fuel, fruit \\
\hline & Pyrus malus L. & Seb & 750 & 68.6 & 15.0 & 0.2 & $\mathrm{P}$ & Fruit \\
\hline & Prunus communis Huds. & Plum & 130 & 26.5 & 4.2 & 0.4 & $\mathrm{P}$ & Fruit \\
\hline & Prunus armeniaca $\mathrm{L}$. & Khumani & 40 & 8.7 & 1.4 & 1.1 & $\mathrm{P}$ & Fruit \\
\hline & Prunus avium L. & Chery & 30 & 0.5 & 0.8 & 0.8 & $P$ & Fruit \\
\hline & Crataegus songarica $\mathrm{G}$. Koch & Pingyat & 50 & 4.8 & 0.9 & 5.6 & $\mathrm{~N}$ & Fuel, Fodder \\
\hline & Salix acmophylla Boiss. & $\begin{array}{l}\text { Jangli } \\
\text { beli }\end{array}$ & 840 & 97.9 & 16.4 & 0.3 & $\mathrm{~N}$ & Fuel, fodder, baskets \\
\hline & Total & - & 1910 & 220.9 & 41.4 & 8.8 & - & - \\
\hline \multirow[t]{8}{*}{ Shrubs } & $\begin{array}{l}\text { Hippophae rhamnoides L. ssp. } \\
\text { turkestanica Rousi }\end{array}$ & $\begin{array}{l}\text { Sarla, } \\
\text { chharma }\end{array}$ & 5110 & 201.6 & 58.2 & 0.2 & $\mathrm{~N}$ & Fuel, ketchup, pickle \\
\hline & Rosa webbiana Wall ex. Royle & Shyabala & 3950 & 5.3 & 44.4 & 0.1 & $\mathrm{~N}$ & Fuel, fencing \\
\hline & Berberis pseudumbelata Parker & Kirmali & 180 & 0.4 & 2.3 & 1.4 & $\mathrm{~N}$ & Fuel, fencing, medicine \\
\hline & $\begin{array}{l}\text { Lonicera quinquelocularis Hard- } \\
\text { wp. }\end{array}$ & Kharmu & 310 & 1.5 & 4.3 & 0.6 & $\mathrm{~N}$ & Fuel, fodder \\
\hline & Lonicera hypoleuca Decne & Kharmu & 140 & 1.2 & 1.2 & 16.7 & $\mathrm{~N}$ & Fuel, fodder \\
\hline & Ribes grossularia L. & Pilickcha & 230 & 0.4 & 2.3 & 3.1 & $\mathrm{~N}$ & Fuel, fencing \\
\hline & $\begin{array}{l}\text { Cotoneaster microphylla Wall. ex } \\
\text { Lindl. }\end{array}$ & Roktali & 50 & 0.2 & 0.6 & 5.6 & $\mathrm{~N}$ & Fuel, fodder \\
\hline & Total & - & 9970 & 210.6 & 113.3 & 27.6 & - & - \\
\hline Grand total & - & - & 16860 & 1636.9 & 300.0 & 39.6 & - & - \\
\hline
\end{tabular}

cies were established around the village settlements to protect the villages from snow slides and to meet fodder and fuelwood requirements.

\section{Agroforestry system}

In the agroforestry system of Jahlmanal watershed, 20 species were found (6 tree species, 7 small trees and 7 shrubs), which provide fodder, fuelwood and other requirements to the farmers (Tab. 1). S. fragilis (3340 trees $\mathrm{ha}^{-1}$ ) had the highest tree density, followed by Juniperus macropoda (700 trees $\left.\mathrm{ha}^{-1}\right)$, P. nigra (590 trees $\left.\mathrm{ha}^{-1}\right)$, Robinia pseudoacacia (180 trees $\left.\mathrm{ha}^{-1}\right), P$. cornuta $\left(130\right.$ trees $\left.\mathrm{ha}^{-1}\right)$ and Juglans regia (40 trees $\left.\mathrm{ha}^{-1}\right)$. Similarly, the importance value index (IVI) was highest for S. fragilis (100.8) followed by P. nigra (20.4), J. macropoda (16.7), R. pseudoacacia (2.8), P. cornuta (2.6) and Juglans regia (2.0). Basal area was also recorded highest for $S$. fragilis (961.8 $\left.\mathrm{cm}^{2} / 100 \mathrm{~m}^{2}\right), P$. nigra $\left(142.8 \mathrm{~cm}^{2} / 100 \mathrm{~m}^{2}\right)$ and $R$. pseudoacacia $\left(9.1 \mathrm{~cm}^{2} / 100 \mathrm{~m}^{2}\right)$, respectively.
Among the small trees, the highest density and basal area were for Pyrus malus (750 trees $\mathrm{ha}^{-1} ; 68.6 \mathrm{~cm}^{2} / 100 \mathrm{~m}^{2}$ ) followed by Prunus communis (130 trees $\mathrm{ha}^{-1} ; 26.5$ $\mathrm{cm}^{2} / 100 \mathrm{~m}^{2}$ ). Other species such as $M$. baccata, C. songarica, $P$. armeniaca and $P$. avi$u m$ had very poor distribution in terms of density and basal area. Among the shrubs, the highest density, IVI, and basal area were recorded for $H$. rhamnoides $(5110$ bushes ha${ }^{1} ; 58.2 ; 201.6 \mathrm{~cm}^{2} / 100 \mathrm{~m}^{2}$ ) followed by Rosa webbiana $\left(3950\right.$ bushes $\mathrm{ha}^{-1} ; 44.4 ; 5.3$ $\left.\mathrm{cm}^{2} / 100 \mathrm{~m}^{2}\right)$. H. rhamnoides was widely distributed along the margins of agricultural fields and in patches along the grasslands and streams.

In the watershed, $30 \%$ trees, $35 \%$ small trees and 35\% shrubs species comprised the agroforestry system. Shrubs contributed highest density (59.1\% of the total) followed by trees $(29.5 \%)$ and small trees $(11.3 \%)$. The trees had highest basal area $(73.6 \%$ of the total); there was not much difference between basal area of small trees and bushes. The IVI values were highest for trees $(48.5 \%$ of total) in the agroforestry system followed by bushes and small trees (13.8\%).

\section{Forestry}

In the forestry systems a total of 15 species were found around settlements. Of these, 5 were tree species, 6 small trees and 4 shrub species (Tab. 2). S. fragilis was the most dominant species and recorded the highest density (5520 trees $\mathrm{ha}^{-1}$ ) followed by $P$. nigra (350 trees ha $\left.{ }^{-1}\right)$ and J. macropoda (160 trees $\left.\mathrm{ha}^{-1}\right)$. The highest IVI values was recorded for $S$. fragilis (186.3) followed by $P$. nigra (20.1), J. macropoda (6.0), P. cornuta (1.9) and R. pseudoacacia (1.1). Basal area, more or less, has also shown the similar trend.

Among the small trees, highest density was noticed for $M$. baccata $\left(80\right.$ trees ha $\left.{ }^{-1}\right)$ and the lowest for $C$. songarica and Salix acmophylla. However, M. baccata had the highest IVI and basal area $\left(4.0 ; 15.4 \mathrm{~cm}^{2} / 100 \mathrm{~m}^{2}\right)$ followed by $P$. communis $\left(2.5 ; 12.6 \mathrm{~cm}^{2} / 100\right.$ $\mathrm{m}^{2}$ ). Among the shrubs, H. rhamnoides and $R$. webbiana were most important species in 
Tab. 2 - Density, basal area, important value indices, abundance frequency ratio and nature of different plant species occurred in forestry in the Jahlmanal watershed, the Lahaul valley. $(\mathrm{P})=$ planted species, $(\mathrm{N})=$ naturally regenerating species.

\begin{tabular}{|c|c|c|c|c|c|c|c|}
\hline Group & Species & $\begin{array}{l}\text { Local } \\
\text { name }\end{array}$ & $\begin{array}{l}\text { Density } \\
\text { ha }^{-1}\end{array}$ & $\begin{array}{c}\text { Basal Area } \\
\left(\mathrm{cm}^{2} / 100 \mathrm{~m}^{2}\right)\end{array}$ & IVI & $\mathbf{A} / \mathbf{F}$ & Nature \\
\hline \multirow[t]{6}{*}{ Trees } & Salix fragilis $\mathrm{L}$. & Beli & 5520 & 1588.4 & 186.3 & 0.1 & $\mathrm{P}$ \\
\hline & Populus nigra $\mathrm{L}$. & Safeda & 350 & 85.3 & 20.1 & 0.1 & $\mathrm{P}$ \\
\hline & Robinia pseudoacacia L. & Kikar & 40 & 2.0 & 1.1 & 4.0 & $P$ \\
\hline & $\begin{array}{l}\text { Juniperus macropoda } \\
\text { Boiss. }\end{array}$ & Shur & 160 & 15.0 & 6.0 & 0.4 & $\mathrm{~N}$ \\
\hline & $\begin{array}{l}\text { Prunus cornuta (Wall. ex } \\
\text { Royle) Steudel }\end{array}$ & Kurun & 50 & 4.4 & 1.9 & 1.3 & $\mathrm{~N}$ \\
\hline & Total & - & 6120 & 1695.2 & 215.4 & 5.9 & $\mathrm{~N}$ \\
\hline \multirow{7}{*}{$\begin{array}{l}\text { Small- } \\
\text { trees }\end{array}$} & Malus baccata (L.) Borkh. & Leejho & 80 & 15.4 & 4.0 & 0.5 & $\mathrm{~N}$ \\
\hline & Pyrus malus L. & Seb & 20 & 1.8 & 0.9 & 2.0 & $P$ \\
\hline & Prunus communis Huds. & Plum & 60 & 12.6 & 2.5 & 1.5 & $\mathrm{P}$ \\
\hline & Prunus armeniaca L. & Khumani & 20 & 4.8 & 1.1 & 2.0 & $P$ \\
\hline & $\begin{array}{l}\text { Crataegus songarica } \mathrm{G} . \\
\text { Koch }\end{array}$ & Pingyat & 10 & 1.1 & 0.8 & 1.0 & $\mathrm{~N}$ \\
\hline & Salix acmophylla Boiss. & Jangli beli & 10 & 1.2 & 0.8 & 1.0 & $\mathrm{~N}$ \\
\hline & Total & - & 200 & 36.9 & 10.0 & 8.0 & $\mathrm{~N}$ \\
\hline \multirow[t]{5}{*}{ Shrubs } & $\begin{array}{l}\text { Hippophae rhamnoides L. } \\
\text { ssp. turkestanica Rousi }\end{array}$ & $\begin{array}{l}\text { Sarla, } \\
\text { Chharma }\end{array}$ & 1660 & 65.5 & 31.0 & 0.5 & $\mathrm{~N}$ \\
\hline & $\begin{array}{l}\text { Rosa webbiana Wall ex. } \\
\text { Royle }\end{array}$ & Shyabala & 1590 & 2.1 & 36.2 & 0.1 & $\mathrm{~N}$ \\
\hline & $\begin{array}{l}\text { Berberis pseudumbelata } \\
\text { Parker }\end{array}$ & Kirmali & 150 & 0.4 & 2.7 & 3.8 & $\mathrm{~N}$ \\
\hline & Ribes grossularia L. & Pilickcha & 230 & 0.4 & 4.7 & 1.4 & $\mathrm{~N}$ \\
\hline & Total & - & 3630 & 68.4 & 74.6 & 5.8 & $\mathrm{~N}$ \\
\hline $\begin{array}{l}\text { Grand } \\
\text { total }\end{array}$ & - & - & 9950 & 1800.6 & 300.0 & 19.7 & - \\
\hline
\end{tabular}

terms of density, IVI and basal area. In forestry, trees were prominent in terms of density, basal area and IVI occupying $61.5 \%$ of total density, $94.2 \%$ of total basal area and $71.8 \%$ of total IVI, respectively.

\section{Forest}

In the forest, a total 6 plant species were recorded, dominated by stunted $J$. macropoda trees, the others being bushes (Tab. 3). The bushes $R$. webbiana, Berberis peudumbe-

lata, Cotoneaster microphylla, Ribes grossularia and Juniperus communis were sparsely distributed. J. macropoda had highest density (4200 trees ha $\left.{ }^{-1}\right)$, IVI (205.9) and basal area $\left(394.6 \mathrm{~cm}^{2} / 100 \mathrm{~m}^{2}\right)$. Among the shrubs, $R$. webbiana was the most important species in terms of density, IVI and basal area. Other species were found poor in terms of distribution. J. macropoda occupied $60.3 \%$ density of entire forest, $98.7 \%$ basal area and $68.6 \%$ IVI, whereas density, basal area and IVI for

Tab. 3 - Density, basal area, important value indices and abundance frequency ratio of different plant species occurred in the forest of Jahlmanal watershed, the Lahaul valley.

\begin{tabular}{|c|c|c|c|c|c|c|}
\hline Group & Species & Local name & $\begin{array}{c}\text { Density } \\
\text { ha }^{-1}\end{array}$ & $\begin{array}{c}\text { Basal Area } \\
\left(\mathrm{cm}^{2} / 100 \mathrm{~m}^{2}\right)\end{array}$ & IVI & $\mathbf{A} / \mathbf{F}$ \\
\hline \multirow[t]{2}{*}{ Trees } & Juniperus macropoda Boiss. & Shur & 4200 & 394.6 & 205.9 & 0.2 \\
\hline & Total & - & 4200 & 394.6 & 205.9 & 0.2 \\
\hline \multirow[t]{6}{*}{ Shrubs } & $\begin{array}{l}\text { Rosa webbiana Wall } \\
\text { ex. Royle }\end{array}$ & Shyabala & 2080 & 2.8 & 73.7 & 0.1 \\
\hline & $\begin{array}{l}\text { Berberis pseudumbelata } \\
\text { Parker }\end{array}$ & Kirmali & 210 & 0.5 & 5.7 & 2.7 \\
\hline & Ribes grossularia $\mathrm{L}$. & Shyabala & 30 & 0.1 & 1.7 & 1.4 \\
\hline & $\begin{array}{l}\text { Cotoneaster microphylla } \\
\text { Wall. ex Lindl. }\end{array}$ & Roktali & 240 & 1.1 & 7.5 & 1.3 \\
\hline & Juniperus communis L. & Path & 200 & 0.6 & 5.5 & 2.5 \\
\hline & Total & - & 2760 & 5.0 & 94.1 & 8.0 \\
\hline Grand total & - & - & 6960 & 399.6 & 300.0 & 8.2 \\
\hline
\end{tabular}

shrubs were $39.7 \%, 1.3 \%$ and $31.4 \%$, respectively.

\section{Vegetation characteristics}

Species richness was higher under agroforestry system followed by forestry and forest (Tab. 4, Tab. 5). The major species under agroforestry and forestry were $S$. fragilis, $P$. nigra and $H$. rhamnoides, whereas J. macropoda was in forests. The dominance concentration was recorded lowest for agroforestry system $(0.2)$ and highest for forest $(0.5)$. Diversity index was highest for agroforestry system (2.0) and lowest for $J$. macropoda forest (1.0). Evenness was higher under agroforestry system followed by forest and forestry. The species richness among the three systems were significantly different $(\mathrm{F}=95.45 ; \mathrm{P}<0.01)$. The species richness was found declining with increase in elevation. The density $(\mathrm{F}=60.20 ; \mathrm{P}<0.01)$ and dominance concentration ( $\mathrm{cd}-\mathrm{F}=39.99$; $\mathrm{P}<0.01$ ) among the three systems was found significantly different.

Tab. 4 - Characteristics of different vegetation types in the Jahlmanal watershed, the Lahaul valley.

\begin{tabular}{lccc}
\hline \multicolumn{1}{c}{ Attributes } & $\begin{array}{c}\text { Agro- } \\
\text { forestry }\end{array}$ & Forestry & Forest \\
\hline $\begin{array}{l}\text { Species } \\
\text { richness }\end{array}$ & 20.0 & 15.0 & 6.0 \\
$\begin{array}{l}\text { Dominance } \\
\text { Concentration }\end{array}$ & 0.2 & 0.4 & 0.5 \\
$\begin{array}{l}\text { (CD) } \\
\begin{array}{l}\text { Diversity } \\
\text { Index (H') }\end{array}\end{array}$ & 2.0 & 1.4 & 1.0 \\
$\begin{array}{l}\text { Evenness } \\
\text { Index (J') }\end{array}$ & 0.7 & 0.5 & 0.6 \\
\hline
\end{tabular}

\section{Discussion}

\section{Vegetation analysis}

In the Jahlmanal watershed, the farmers have maintained tree species on edges and boundaries of terraced agricultural fields under low density. The agroforestry system has been developed to meet some parts of fodder, fuelwood and minor timber requirements (Rawat et al. 2006). S. fragilis and $P$. nigra are the two most successful tree species in the cold desert environment, hence they are maintained under this agroforestry system. Vishvakarma et al. (1998) in their study of indigenous agroforestry system in the Kullu valley found that the farmers maintained Grewia oppositifolia in high density to meet fodder, fuelwood and fibre requirements in temperate climatic conditions. Similarly, S. fragilis is the most successful tree species in the Lahaul valley found below $3000 \mathrm{~m}$ altitude; above this altitude high tree mortality $(55.2 \%)$ was found particularly in 
Tab. 5 - Comparative species richness, density, basal area and important value indices in the Jahlmanal watershed, the Lahaul valley.

\begin{tabular}{llcrrr}
\hline \multirow{2}{*}{ Sector } & \multicolumn{1}{c}{ Groups } & $\begin{array}{c}\text { No. of } \\
\text { Species }\end{array}$ & Density & Basal area & IVI \\
\hline Agroforestry & Tree & 6 & 4980 & 1205.4 & 145.3 \\
& Small-tree & 7 & 1910 & 220.9 & 41.4 \\
& Shrub & 7 & 9940 & 210.6 & 113.3 \\
& Total & 20 & 16860 & 1636.9 & 300.0 \\
\hline Forestry & Tree & 5 & 6120 & 1695.2 & 215.4 \\
& Small-tree & 6 & 200 & 36.9 & 10.0 \\
& Shrub & 4 & 3630 & 64.4 & 74.6 \\
& Total & 20 & 9950 & 1800.6 & 300.0 \\
\hline Forest & Tree & 1 & 4200 & 394.6 & 205.9 \\
& Shrub & 5 & 2760 & 5.0 & 94.1 \\
& Total & 6 & 6960 & 399.6 & 300.0 \\
\hline
\end{tabular}

Khoksar area (Rawat et al. 2006). Growing trees along the edges in the agricultural field is an age-old practice in the Indian Himalaya. There are a variety of multipurpose tree species grown and managed for subsistence requirement of local communities (Maikhur et al. 2000, Vishvakarma et al. 1998) such as fuelwood, timber, fruits and raw materials. The most important aspect of the agroforestry and forestry systems is lessening the anthropogenic pressure on natural forests (Rao \& Maikhuri 1996, Nautiyal \& Negi 1994, Vishvakarma et al. 1998). In the forest system only well adapted species such as $J$. macropoda and $R$. webbiana can survive under extremely xeric soil conditions of south facing slopes. $J$. macropoda is one of the most successful tree species on the south facing dry and xeric slopes (Aswal \& Mehrotra 1994). The species richness in agroforestry systems in the watershed was relatively higher than in forest. This is because the farmers maintained these plants in agroforestry, hence these plants fulfill the fodder and fuelwood requirements of the farmers.

Among the small trees, Pyrus malus (apple) is being introduced as a new cash crop. S. acmophylla (a wild willow) natural grown under agroforestry system was maintained as a basic source of energy and raw material for making baskets. Therefore, these two species are found under agroforestry system with relatively higher density. Among the shrubs, $H$. rhamnoides was found relatively higher density and distributed along the margins of agricultural fields, grasslands and along the streams in the watershed. It has a nitrogen fixing ability through microbial association helps in land restoration (Rongsen 1992). However, $R$. webbiana, forms tussocks in degraded forests and grasslands. It was widely distributed in the watershed except on stony outcrops and snowbound areas. Tussocks of $R$. webbiana hold soil, check soil erosion and survive under extreme climatic conditions of the cold desert. H. rhamnoides was used as fuelwood, making agricultural implements, and the fruits are used for juice and ketchup. $R$. webbiana used as a fencing material and fuelwood. Regular irrigation through $\mathrm{kuhl}$ promotes natural regeneration of local species under agroforestry and forestry systems.

The plantations of $S$. fragilis and P. nigra provides a major share of fuelwood requirement for domestic use and a large portion of green fodder during winter months. Small trees like $P$. malus, $P$. communis and $P$. armeniaca are planted in a low density for their edible fruits of domestic use. All the shrub species under plantations grow naturally and are used as fuelwood, fodder and fencing materials. The relict patches $J$. $m a-$ cropoda in the watershed are highly degraded as a result of intensive wood, leaves removal and grazing animals. J. macropoda tolerates the extremely xeric soils of the cold desert. In the past, Pinus wallichiana was also found among the J. macropoda trees (Harcourt 1870). In the lower part of the Pattan valley in the Lahaul valley, $P$. wallichiana is still found with very low density. Excessive removals of the trees in the past have been a major cause of its elimination from the system. J. macropoda has been a major timber species in the watershed since the past but nowadays it is almost distributed in the relict patches. Ecologically, it is an important evergreen plant species in the region. So this species socio-culturally has become a part and parcel of a social system of the local communities.

\section{Vegetation characteristics}

In the agroforestry and forestry systems, several indigenous plant species have regenerated under natural conditions, besides the plantation of $S$. fragilis, $P$. nigra, $P$. malus, $P$. communis and $P$. armeniaca, whereas in forest only drought resistant species are survived. This was evident in reflecting species richness, evenness and diversity index of the agroforestry and forestry as compared to forest. Species richness was highest at inter- mediate level of $\mathrm{pH}$ in Norderney (North Sea Germany) and Baltic coast of MecklenburgVorpommern in the north-eastern Germany from Rostock eastward (Issermann 2005. This study supported the present study. Saxena \& Singh (1982) recorded high species richness (4 to 22 ) and diversity (0.74 to 3.10$)$ for the shrub layer in the Kumaun Himalaya, which is comparable to the present study. The values of dominance concentration (cd) were similar to those reported by Whittaker (1965) and Risser \& Rice (1971) for temperate vegetation $(0.01$ to 0.99$)$. Saxena \& Singh (1982), and Tiwari \& Singh (1985) reported the values of 0.11 to 1.00 for different forests in the Kumaun Himalaya. Species diversity was under agroforestry and forest systems are comparable with values generally reported for temperate forests (Monk 1967, Singh \& Singh 1987). The species diversity was found lower than reported by Risser \& Rice (1971) which ranged from 2.00 to 3.00 for temperate forest. The vegetation of the watershed was shown a sparse distribution pattern due to xeric climatic conditions. There were considerable differences in the species composition of vegetation in the watershed.

\section{Conclusions}

The available relict forest patches in the Jahlmanal watershed are degrading fast due to high anthropogenic pressures, hence $i n-s$ $i t u$ and ex-situ conservation measures are urgently required. These patches are subjected to deforestation and fragmentation in many ways due to extraction of timber, fuelwood, fodder, leaves and medicinal plants, etc. A systematic and scientific research is required for mass multiplication and revival of Juniperus forests in the watershed. Efforts are urgently required for plantation of grasses, bushes (Seabuckthorn) and multipurpose tree species (Salix spp. and Populus spp.) with indigenous species, ecologically suitable for the xeric cold desert environment. Technological interventions are also required to improve the quality and resistance against drought and climate change. The plants need to be distributed among the local people to plant these species in their own private land for woods and leaves based requirements. Seed orchards and arboretum establishment is also suggested for mass multiplication of the existing valuable plant taxa. The utilization pattern of a particular plant species also provides valuable information on the status, their use pattern and dependency of the local communities on plant species.

\section{Acknowledgements}

We thankful to the Dr. L.M.S. Palni, Director, G.B. Pant Institute of Himalayan Environment and Development, Kosi-Katarmal, Almora, Uttarakhand, for providing necessary facilities. Financial support to conduct 
the present study by the Ministry of Environment and Forests, Govt. of India is highly acknowledged with thanks. The first author is also thankful to the Council of Scientific and Industrial Research, New Delhi for awarding Senior Research Fellowship. The anonymous reviewers are acknowledged with thanks for their helpful comments to improve the manuscript.

\section{References}

Anonymous (1993). Action plan on cold desert: an integrated approach for sustainable development. Regional center, NAEB, UHF, Solan, pp. 1-40. Anonymous (1995). Annual report. G.B. Plant Institute of Himalayan Environment and Development, Kosi-Katarmal, Almora (India), pp. 55-56. Aswal BS, Goel AK (1989). Alpine flora in west Himalayan mountain of India: a curious view. Himalayan Research and Development 8: 10-13.

Aswal BS, Mehrotra BN (1994). Flora of LahualSpiti. A cold desert in north west Himalaya. Bishen Singh, Mahendra Pal Singh, Dehradun, India, pp. 10-15.

Curtis JT (1959). The vegetation of Wisconsin: an ordination of plant communities. University of Wisconsin Press, Madison, Winconsin, USA.

Curtis JT, Cottom G (1956). Plant ecology workbook. Laboratory field production in Andropogon gerardi. Ecology 31: 488-489.

Curtis JT, McIntosh RR (1950). The interrelations of certain analytic and synthetic phytosociological characters. Ecology 46: 84-89.

Dhar U, Vir J, Kachroo P (1994). Ladhak: an update on natural resources. In: "High altitudes of the Himalaya - Biogeography, ecology and conservation" (Pangety YPS, Rawal RS eds). pp. 102-114.

Harcourt AFP (1870). The Himalayan district of Koloo, Lahaul and Spiti. Vivek Publishing House (reprint 1972), Delhi, India, pp. 74.

Issermann M (2005). Soil $\mathrm{pH}$ and species diversity in coastal dunes. Plant Ecology 178:111-120. doi: 10.1007/s11258-004-2558-8

Kershaw KK (1973). Quantitative and dynamic plant ecology. ELBS and Edward Arnold Publishers Ltd. London, pp. 308.

Knight DH (1963). A distance method for constructing forest profile diagram and obtaining structural data. Tropical Ecology 4: 89-94.

Kuniyal CP, Rawat YS, Oinam SS, Kuniyal JC, Vishvakarma SCR (2005). Kuth (Saussurea lappa) cultivation in the cold desert environment of the Lahaul valley, northwestern Himalaya, India: arising threats and need to revive socio-economic. Biodiversity and Conservation 14 (5): 1035-1045. - doi: 10.1007/s10531-004-4365-x

Kuniyal CP, Vishvakarma SCR, Kuniyal JC, Singh GS (2002). Seabuckthorn (Hippophae L). A promising plant for land-restoration in the cold desert Himalayas. In: "Proceedings of International Workshop on Seabuckthorn" (Singh V, Khosla PK eds). Feb. 18-21 2002, New Delhi, India, pp. 1-6.
Kuniyal JC, Vishvakarma SCR, Singh GS (2004). Changing crop biodiversity and resource use efficiency of traditional versus introduced crops in cold desert of north-western Indian Himalaya: a case of Lahaul valley. Biodiversity and Conservation 13 (7): 1271-1304. - doi: 10.1023/ B:BIOC.0000019404.48445.27

Mac Arthur RH (1965). Pattern of species diversity. Biological Review 40: 510-533. - doi: 10.1111/j.1469-185X.1965.tb00815.x

Maikhuri RK, Semwal RL, Rao KS, Singh K, Saxena KG (2000). Growth and ecological impacts of traditional agroforestry tree species in central Himalaya, India. Agroforestry Systems 48: 257272. - doi: 10.1023/A:1006344812127

Monk CD (1967). Tree species diversity in the eastern deciduous forest with particular references to north central Florida. American Naturalist 10: 173-187.

Nautiyal AR, Negi GCS (1994). Multipurpose tree species with potential for introduction in agroforestry system in Himalayan mountains. In: "Agroforestry system for degraded lands" (Singh P, Pathak PS, Roze MM eds). Oxford \& IBH publishing co-pvt-Ltd, New Delhi, India, pp. 269-278.

Oinam SS, Rawat YS, Khoiyangbam RS, Khwairakpam G, Kuniyal JC, Vishvakarma SCR (2005). Land use and land cover changes in Jahlma watershed of the Lahaul valley, India. Journal of Mountain Science 2 (2): 129-136. - doi: 10.1007/BF02918328

Phillips EA (1959). Methods of vegetation study. Henry Holt and Co. Inc., New York, USA.

Pielou EC (1966). The measurement of diversity in different types of biological collections. Journal Theoretical Biology 13: 131-144.

Rao KS, Maikhuri RK (1996). Agroforestry for sustainable development of rural people ecosystem of central Himalaya. Proceedings of the "IUFRO-DNAES international meeting on resource inventory techniques to support agroforestry and environment activities" (Kohali RK, Arya KS eds). Dyanand National Academy of Environmental Science, DAV. Collage. Chandigarh (India) Oct 1-3 1996, pp. 301-305.

Rawat YS, Oinam SS, Vishvakarma SCR, Kuniyal JC (2004). Saussurea costus (Falc.) Lipsch: a promising medicinal crop under cold desert agroecosystem in north-western Himalaya. Indian Journal of Forestry 27 (3): 297-303.

Rawat YS, Oinam SS, Vishvakarma SCR, Kuniyal CP, Kuniyal JC (2006). Willow (Salix fragilis Linn.): a multipurpose tree species under pest attack in the cold desert of Lahaul valley, northwestern Himalaya, India. Ambio 35 (1): 43-48.

Rawat YS (2006). Vegetational analysis, socio-economic and cultural aspects of Salix sp. in cold desert environment of the Lahaul valley, northwestern Himalaya (HP). Ph.D. Thesis, Garhwal University, Srinagar Garhwal, UK-India, pp. xiii+270.

Risser PG, Rice EL (1971). Diversity in tree species in Oklahoma upland forest species. Ecology
52: 876-880. - doi: 10.2307/1936036

Rongsen L (1992). Seabuckthorn: a multipurpose plant species for fragile mountains. International centre for integrated mountain development (ICIMOD), Occasional Paper No. 20, Kathmandu, Nepal, pp.1-62.

Saxena AK, Singh JS (1982). A phytosociological analysis of woody species in forest communities of a part of Kumaun Himalaya. Vegetatio 50: 332. - doi: 10.1007/BF00120674

Shannon CE, Weiner W (1963). The mathematical theory of communication. University Illinois Press, Urbana, USA, pp.17.

Simpson EH (1949). Measurement of diversity. Nature 163: 668.

Singh GS, Ram SC, Kuniyal JC (1997). Changing traditional land use patterns in the Great Himalayas: a case study of Lahaul Valley. Journal of Environmental Systems 25 (2): 195-211.

Singh JS, Singh SP (1987). Forest vegetation of the Himalaya. Botanical Review 52: 82-192. doi: 10.1007/BF02858183

Snedecor GW, Cochran WG (1968). Statistical methods. Oxford and IBH publishing Co., New Delhi, India.

Sood SK, Nath R, Kalia DC (2001). Ethnobotany of cold desert tribes of Lahaul-Spiti (NW, Himalaya). Deep Publication, New Delhi, India, pp. 228

Tiwari JC, Singh SP (1985). Analysis of woody vegetation in a mixed Oak forest of Kumaon Himalaya. Proc. Indian Sci. Acad. 332-345.

Vishvakarma SCR, Kuniyal JC, Singh GS (1998). Indigenous agroforestry system of north western Himalaya. Research for mountain development: some initiative and accomplishment. Gyanodaya Prakashan, Nainital, Uttarakhand, India, pp. 99118.

Vishvakarma SCR, Rawat YS, Oinam SS, Kuniyal JC (2005a). Irrigation (Kuhls): a community management system in cold desert of the Lahaul valley, northwestern Himalaya, India. In: Proceedings of the "Third international seminar on farmer managed irrigation systems and governance alternatives" (Pradhan P, Gautam U eds). Kathmandu (Nepal), Sep 9-10 2004, pp. 425-444.

Vishvakarma, SCR, Kuniyal JC, Rawat YS, Oinam SS (2005b). Impact of anthropogenic activities on Bio-resource in cold desert of Lahaul valley, north-western Himalaya. Submitted to the Ministry of Environment \& Forests, New Delhi, India. F. No. 10/35/99-CS/BR of $10^{\text {th }}$ April 2000, pp. 190.

Watt G (1981). Notes on vegetation of Chamba state and British Lahul. J. Linn. Soc. Bot. 18: 368-382. - doi: 10.1111/j.1095-8339.1881. tb01260.x

Whittaker RH (1965). Dominance and diversity in land plant communities. Science 147: 250-260. doi: 10.1126/science.147.3655.250

Whittaker RH (1975). Communities and ecosystem $\left(2^{\text {nd }}\right.$ edn $)$. Macmillan publishing Co. New York, pp. 385. 